\title{
Physico - microbiological and chemical examination of domestic water used by the college of agriculture community, Maiduguri, North- Eastern Nigeria
}

\author{
Gwana, A. M. ${ }^{1,}{ }^{*}$, Bako, M. M. ${ }^{2}$, Auwal, M. S. ${ }^{3}$, Bagudu, B. Y. ${ }^{4}$, Kadai, K. I. ${ }^{5}$, Sadiq, A. B. ${ }^{6}$, \\ Halima, M. B. ${ }^{7}$ \\ ${ }^{1}$ Laboratory Unit, Department of Animal Health and Production Technology, Mohamet Lawan College of Agriculture, P.M.B. 1427, \\ Maiduguri, Nigeria \\ ${ }^{2}$ Department of Fisheries, Faculty of Agriculture, University of Maiduguri, P.M.B 1069, Maiduguri, Nigeria \\ ${ }^{3}$ Department of veterinary Physiology, Pharmacology and Biochemistry, University of Maiduguri, P.M.B 1069, Maiduguri, Nigeria \\ ${ }^{4}$ Department of Science Laboratory Technology, Waziri Umaru Federal Polytechnic, Birnin Kebbi, Kebbi State, Nigeria \\ ${ }^{5}$ Department of Animal Health and Production Technology, Mohamet Lawan College of Agriculture, P.M.B. 1427, Maiduguri, Borno \\ State, Nigeria \\ ${ }^{6}$ Department of Biochemistry, University of Maiduguri, P.M.B 1069, Maiduguri Nigeria \\ ${ }^{7}$ Department of Basic Science, Mohamet Lawan College of Agriculture, P.M.B. 1427, Maiduguri, Nigeria
}

\section{Email address:}

admuwana@yahoo.com (Gwana A. M.), mammadu09@gmail.com (Bako M. M.), mshaibu68@yahoo.com (Auwal M. S.), hutawas@yahoo.co.uk (Bagudu B. Y.), kadaiki63@gmail.com (Kadai K. I.), a.aaji2k6@yahoo.com (Sadiq A. B.), Halima.mohmmedbala@yahoo.com (Halima M. B.)

\section{To cite this article:}

Gwana, A. M., Bako, M. M., Auwal, M. S., Bagudu, B. Y., Kadai, K. I., Sadiq, A. B., Halima, M. B.. Physico - Microbiological and Chemical Examination of Domestic Water Used by the College of Agriculture Community, Maiduguri, North- Eastern Nigeria. International Journal of Science, Technology and Society. Vol. 2, No. 4, 2014, pp. 63-68. doi: 10.11648/j.ijsts.20140204.11

\begin{abstract}
This study was conducted on physico - microbiological and chemical examination of domestic water used by the community, College of Agriculture, Maiduguri, North - Eastern Nigeria. $200 \mathrm{mls}$ of water samples were randomly collected from seven stations. Methods been applied are physical, microbiological and chemical techniques as described by Cheesbrough, (2010) and AOAC, (1990). Physical parametric values were obtained and falls within the W.H.O. recommended standard values, except one station, in term of turbidity. Presumption coliform count, confirmatory total coliform test, plate count yielded Coliform and Escherichia coli count which exceeded therecommended values. Aerobicmesophilic bacterial count was performed, and met the recommended values limit for safe drinking water. No parasites found from examinat-ion of the water sampled. Elements determined in the water sampled exceeded the W.H.O recommended standard values; chromium in stations $\mathrm{E}(0.06 \mathrm{mg} / \mathrm{l})$, lead $(0.02 \mathrm{mg} / \mathrm{l})$ and $\mathrm{G}(0.06 \mathrm{mg} / \mathrm{l})$, manganese in stations A $(0.25 \mathrm{mg} / \mathrm{l}), \mathrm{B}(0.17 \mathrm{mg} / \mathrm{l})$ and $\mathrm{G}(0.13 \mathrm{mg} / \mathrm{l})$, which make the water unwholesome for consumption. Data obtained were subjected to statistical analysis, found significance. Conclusively, water used by this community is found fit for consumption in terms of both physical and parasites free, but, unfit in terms of faecal and some chemicals contamination. Government, NGOs or any authority concerned should assist and build more bore holes with PVC pipes for safe water distributions, communities should be enlightened on the sanitary measures, safe drinking water and it hygienic purification.
\end{abstract}

Keywords: Chemical, Community, Physical, Parametric, Domestic Water, Microbiological

\section{Introduction}

Water is essential to life, a universal solvent [3], and contains dissolved elements in various quantities; such as heavy metals, e.g., manganese, iron, lead, zinc, e.t.c, [8].
Water is also used for domestic purposes which include drinking, food preparation, washing of clothes, keeping our selves and environment clean, for garden, etc [1]. These 
factors and many mores, make water a substance of great importance. From a strictly chemical point of view the remarkable thing about water is the amount of hydrogen bonding there is, both in the solid (ice) and in the liquid. If it were not for the fact that hydrogen bonds are of intermediate strength, then life as we know it could not exist and the world would be without rivers, lakes, or seas $[10,11]$. Most of the water used for industrial purposes is returned to the water cycle, and it is often contaminated with microbiological agents, some chemicals and heavy metals $[4,6,10]$. It is important to evaluate the beneficial uses of watershed in order to access the impact of pollution. In overall water budget, human consumption of water for domestic activities and commercial enterprise accounts for a small percentage of annual rainfall. However, human actions have a wide ranging effect on a watershed's hydrologic balance, both in terms of water quality and quantity [5]. According to W.H.O, (2004), stated that, many water sources in developing Countries are unhealthy, this is because, they contained harmful physical, chemical and biological agents. To maintain good health, however, not only must a water supply be safe to drink, it must also be; available in sufficient quantity for cooking, hand washing, personal bathing, cleaning and laundering clothes, easily and safely accessible by all the community without the need to carry heavy containers of water over long distances or having containers of water insects vectors of disease, available all of the time or when it is needed, available at affordable cost and it should also meet local standards for taste, odour, and appearance [9, 14]. A safe drinking water should confirm to the following water quality characteristic it should be free from pathogenic organisms, low in concentration of compounds that are toxic to man, livestock, and plants, and finally free from compounds that causes offensive taste and odour [15]. In a publication, Safe water, better health by World Health Organization in 2008, estimates that almost one tenth $(1 / 10)$ of the global disease burden could be prevented by improving water supply, sanitation, hygiene and management of water resources. It is estimated that 1.5 million children die each year from diarrhoea disease due to unsafe water, inadequate sanitation or insufficient hygiene [9]. Growth and nutrition in young children are also adversely affected by contaminated water supplies, poor hygiene and inadequate sewerage. The United Nations had declared 2005 to 2015 the Water for Life Decade with focus on water - related issues and a goal of having by 2015 the number of people with no access to sustainable safe drinking water and basic acceptable sanitation. Among the issues identified as priority for decade (i.e. safe water, better health - water for life decade) are water scarcities, sanitation access, disaster prevention, Trans boundary water issues, gender issues, capacity building, financing, valuation, integrated water resources management, environment and biodiversity, food and agriculture, pollution and energy. Drinking water standards frequently are referred to as if they are simple lists of standards parametric values $[9,11,13]$.

\subsection{Aims and Objectives of the Study}

To determine the physical, microbiological and chemical contaminations, the lements concentration of the water used for domestic activities by community, College of Agriculture, Maiduguri, North - Eastern Nigeria.

\section{Methodology}

\subsection{Study Area and Location}

The study was conducted within the community of College of Agriculture, Maiduguri, Borno state. The state is located in the North - Eastern region of Nigeria, and is among the six geo - political zones of the Federal Republic Nigeria. Maiduguri shares local boundaries with Konduga, Jere, and Mafa local government areas. It has a few establishment, businessmen and women, but the majority of the local people are small scale business community, farmers, fishermen and herdsmen, Islamic and western scholars. The local farmers usually sow plant crops such as millet, sorghum, cowpea, groundnuts, maize, and some vegetables. They reared livestock such as Cattle, Camel, Sheep, Goat and both local and exotic poultry farming are being practiced. The major languages used in communication are Kanuri, Shuwa-Arab, Hausa and English respectively [7]. According to National population Commission (2006), Maiduguri has an area land-mark of 300 square kilometres $\left(300 \mathrm{~km}^{2}\right)$, which lies between latitude $12^{0}$ North to $13^{0}$ North and longitude $13^{0}$ East to $15^{0}$ East. It has an estimated population of 629,486 people, 340,809 males and 288,977 females. Climatic condition in this area is of a hot dry season $\left(27^{\circ} \mathrm{c}\right.$ to $\left.42^{\circ} \mathrm{c}\right)$ and an annual rainfall of 500 to $600 \mathrm{~mm}$ has been recorded [7].

\subsection{Materials Used}

The following reagents and equipments are used in the execution of this research study, these are;

\subsection{Reagents Used}

Copper tablets (for copper analysis), sodium cyanide solution (for manganese and lead), $0.1 \mathrm{~g}$ of Chromium powder (for chromium), $1.0 \mathrm{ml}$ ammonia and sodium citrate solutions (for cadmium), $0.5 \mathrm{ml}$ of sodium arsenate solution and acid zirconyl (for fluorine), deionized water, distilled water, tap water, and $70 \%$ alcohol solution (as disinfectant).

\subsection{Apparatus used}

$\mathrm{pH}$ meter, thermometer, sterile water sample containers (plastic type), test tubes of various sizes, beakers, automatic pipette, automatic absorption spectrophotometer, filter paper, syringes and cold - chain box.

\subsection{Methods Used}

Methods used in this research study are the physical, 
microbiological and chemical technique as in the methods described by AOAC, (1990) and Cheesbrough, (2010). The methods were divided in to six (6) experimental stages. These stages are: - Water samples collection from eight stations within the study area, measurements of the $\mathrm{pH}$, temperature, turbidity, microbiological and determination of heavy metals by using AAS techniques of water analyses. Experiment stage 1: Water samples collection.

Procedure: - The study area was divided in eight stations namely; A, B, C, D, E, F, and G randomly, i.e. eight water stations were selected from the said area, for the purpose of water sampling. At 6:00 AM hours (in the morning hours), $200 \mathrm{mls}$ of pooled (water collected from various portions of the water source and mixed together) water samples were collected in sterile plastic bottles from each station, properly screw capped and labelled with the following information; date and time of collection, name of the station, and volume of water sample collected, aseptically. The water samples were packed in a cold - chain container and transported into the Laboratory for analysis.

Experiment stage 2: Measurements of the $\mathrm{pH}$ and the temperature of the water samples.

Procedure: - The $\mathrm{pH}$ of the water samples were measured and recorded by using $\mathrm{pH}$ digital meter at the point of sample collection. This was done by deepened the electrodes point of the $\mathrm{pH}$ meter in to the water sample for thirty seconds; it was then rinsed with distilled water and deionised water finally. Also measurement of the temperature were performed by deepened the bulb end for one minute and the readings were recorded, then rinsed with distilled water and deionised water after each reading taken.

Experiment stage 3: Measurements of Turbidity of the water samples by using a calibrated $5-25$ TU Turbidity tube (PT 513).

Procedure: - The two tubes were joined together by pushing the upper tube into the lower one and the black cross at the bottom of the tube was seen and noted. The tube was held over a white surface (a white tile surface), viewed through the tube, the water sample was dispensed slowly into the tube until the black cross is no longer visible. The formation of air bubbles was avoided. The turbidity unit, that is, the graduation which corresponds to the water meniscus (level) was taken and recorded respectively.

Experiment stage 4: - Microbiological (bacteriological) determination of faecal contamination of water sampled by using the plate count, presumption coliform count (multiple tubes technique) and confirmatory coliform test techniques as described by Cheesbrough. (2010).

Plate Count:

Procedure: $-0.1 \mathrm{ml}$ of the water sample was inoculated on to a Nutrient agar plate. The inoculated plate was incubated at $37^{\circ} \mathrm{C}$ for 24 hours. It was done on duplicate plates. After 24 hours, the numbers of the colonies yielded per plate were counted.

Presumption Coliform Count (Multiple Tubes Technique):
Procedure: - Fifteen (15) sterile tubes containing inverted Durham tubes were arranged and divided into 3 set of five. $10 \mathrm{mls}$ of double strength Mac conkey broth medium was dispensed into each of the tube. The first five set were inoculated with $10 \mathrm{mls}$ of the inoculum (water sample), then the second five set of the tubes were inoculated with $1 \mathrm{ml}$ of the inoculum, while the third five set of the tubes were inoculated with $0.1 \mathrm{ml}$ of the inoculum. The tubes were mixed thoroughly and incubated at $37^{\circ} \mathrm{C}$ for twenty four hours ( 24 hours) and up to forty eight hours (48 hours) respectively. It were then observed for any formation of gas production or colour change of the broth from violet to yellow in the inverted Durham tubes within the said incubated period which indicate a positive presumption test.

Confirmatory Total Coliform Test Techniques:

Procedure: - A loopful was taken from the positive culture tubes from the presumption test and inoculated in to Brilliant green broth medium which contains Durham tubes. It was incubated at $37 \pm 0.5^{\circ} \mathrm{C}$ for 24 hours. It was then observed for the presence of gas production which confirms the presence of bacteria. The presence of colonies indicated probable identity for typical Coliform. Green stained portion, shows confirmed Coliform and those with a greenish stain confirms the presence of E. coli, those without any colouration means negative.

Experiment stage 5:- Parasitological examination (microscopically) of water sample.

Procedure: - The water sample was mixed thoroughly by turning container up and down side gently. $10 \mathrm{mls}$ of the mixed sample was dispensed in to a centrifuge tube and screwed capped. The centrifuge tube containing the sample was inserted in to the Centrifuge bucket and balanced it. The centrifuge machine was then set on and adjusted to 2000 revolution per minute for five (5) minutes respectively. The centrifuge machine was allowed to stop by itself after the time period adjusted without disturbing it. It was removed from the centrifuge machine and the supernatant was decanted. The bottom of the tube was rocked and agitated to detach the deposits.

Microscopy: - On to the centre of a clean grease free glass slide, two drops of the deposits was put. It was the covered with a clean grease free cover slip, and oozing of the fluid (deposit) was avoided. It was then mounted on to the stage of the microscope, examined with $\mathrm{x} 10$ and $\mathrm{x} 40$ objective lenses and the results were recorded respectively.

Experiment stage 6: - Determination of parametric values of cadmium, chromium, copper, fluoride, lead, manganese and nitrite in the water sampled.

Procedure: - As described by AOAC, (1990).

Data Analysis Used: - Data that are obtained from this research study are subjected to statistical analysis by using means for the measurement of central tendency, and standard deviations for measurement of dispersion and or discrepancy within the variables, were determined in triplicates, reported in Percentage as described by Stroud \& Booth, (2001). 


\section{Results}

The results obtained from this research study on the physical, microbiological and chemical survey on domestic water used by the community of the College of Agriculture, Maiduguri, North - Eastern Nigeria, where $200 \mathrm{mls}$ of water samples were collected each, from the seven stations; A, B, C, D, E, F and G, are presented in tables and read as followed:

Table 1 showed the physical parametric values of the water sampled; these are the $\mathrm{pH}$, temperature and turbidity measurements. $\mathrm{pH}$ measurement of stations A, B, C, D, E, F and $\mathrm{G}$, are $(6.8,7.0,7.2,8.02,7.18,8.1$, and 8.5). The temperature values in degree Celsius $\left({ }^{\mathrm{O}} \mathrm{C}\right)$ of the water sampled from stations; A $\left(31^{\mathrm{O}} \mathrm{C}\right), \mathrm{B}\left(30^{\mathrm{O}} \mathrm{C}\right), \mathrm{C}\left(29^{\mathrm{O}} \mathrm{C}\right), \mathrm{D}$ $\left(27^{\mathrm{O}} \mathrm{C}\right), \mathrm{E}\left(32^{\mathrm{O}} \mathrm{C}\right), \mathrm{F}\left(30^{\mathrm{O}} \mathrm{C}\right)$ and $\mathrm{G}\left(22^{\circ} \mathrm{C}\right)$. The turbidity in turbidity Unit (TU) of the water sampled from the seven stations; A 4TU, B 2TU, C 2TU, D 1TU, E 3TU, F 4TU and G 5TU.

Table 2 showed the bacteriological examination of the water sampled from stations with respect to the type of Bacterial indicators of water quality; Coliforms, Escherichia coli and Aerobicmesophilic Bacteria. Coliform Count of stations A, B, C, D, E, F and G are (90, 15, 5, 95, 35, 10, and 5) Coli form unit per mls (CFU/ ml). The $E$. coli count are; A 71, B 10, C 20, D 35, E 20, F 45 and G $1 \mathrm{CFU} / \mathrm{ml}$ of water sampled. The Aerobicmesophilic bacterial counts are A, B, C, D, E, F and G $(188,236,0$, 260, 215, 150, and 10) CFU / $\mathrm{ml}$.

Table 3 showed the microscopically examination of the water sampled by using the parasitological techniques of analysis, there was no any Parasite or form of parasite found.

Table 4 showed the concentration levels of the elements analysed from the water sampled, cadmium metal in stations are; A, B, C, D, E, F, and G (0.18, 0.04, 0.08, 0.04, $0.12,0.05$, and 0.03$)$ in milligrams per litre $(\mathrm{mg} / \mathrm{l})$. Chromium metal in stations; A 0.02, B 0, C 0.04, D 0.03, E $0.06, \mathrm{~F} 0.01$, and G $0.05 \mathrm{mg} / \mathrm{l}$. Copper in stations; A 0.32, B 0, C 0.01, D 0.41, E 0.07, F 0, and G $0 \mathrm{mg} / \mathrm{l}$. Fluoride in stations; A 0.08 , B 0.11 , C 0.05 , D 0 , E 0, F 0.03 and G $0.01 \mathrm{mg} / \mathrm{l}$. Lead metal in stations; A 0, B 0, C 0.01, D 0, E 0.02 , F 0.01, and G $0.06 \mathrm{mg} / \mathrm{l}$. Manganese metal in stations; $\mathrm{A}, \mathrm{B}, \mathrm{C}, \mathrm{D}, \mathrm{E}, \mathrm{F}$ and $\mathrm{G}$, and have the following values in $\mathrm{mg} / \mathrm{l}(0.025,0.17,0.02,0,0.03,0.02$, and 0.13$)$. Nitrate in stations; A, B, C, D, E, F and G have the following values in $\mathrm{mg} / \mathrm{l}(0.91,0.09,0.17,0.85,0.57,0.29$ and 1.02). Variables obtained were subjected to statistical analysis and the results obtained are found significant.

Table 1. Showed the Physical Parametric Values of Water Sampled from Stations.

\begin{tabular}{|c|c|c|c|c|c|c|c|c|}
\hline \multirow{2}{*}{$\begin{array}{l}\text { Types of Physical } \\
\text { Parametre. }\end{array}$} & \multicolumn{7}{|c|}{ Stations sampled $(200 \mathrm{mls})}$. & \multirow{2}{*}{ Total $($ Mean \pm SD). } \\
\hline & A. & B. & C. & D. & E. & F. & G. & \\
\hline pH. & 6.8 & 7.0 & 7.2 & 8.02 & 7.18 & 8.1 & 8.5 & $52.8(7.5 \pm 0.7)$ \\
\hline Temperature $\left({ }^{\circ} \mathrm{C}\right)$. & 31 & 30 & 29 & 27 & 32 & 30 & 22 & $201(28.7 \pm 10.6)$ \\
\hline Turbidity (TU). & 4 & 2 & 2 & 1 & 3 & 4 & 5 & $21(3 \pm 1.4)$ \\
\hline
\end{tabular}

Table 2. Showed the Isolates Examined in the Water Sampled from The Stations.

\begin{tabular}{lllllllll}
\hline Types of Bacteria & \multicolumn{7}{l}{ Number of Isolates in Stations sampled (CFU / mls). } & \\
\hline Isolated (Indicators). & A. & B. & C. & D. & E. & F. & G. & Total (Mean \pm SD). \\
\hline Coliform. & 90 & 15 & 5 & 95 & 35 & 10 & 5 & $255(36.4 \pm 46)$. \\
Escherichia coli. & 71 & 10 & 20 & 35 & 20 & 45 & 1 & $202(28.9 \pm 27)$. \\
Aerobicmesophilic Bacteria. & 188 & 236 & 0 & 260 & 215 & 150 & 10 & $1059(151.3 \pm 133.6)$. \\
\hline
\end{tabular}

Table 3. Showed the Water Sampled from the Stations Using Parasitological Technique.

\begin{tabular}{|c|c|c|c|c|c|c|c|c|}
\hline \multirow{2}{*}{ Types of Parasites and forms Searched. } & \multicolumn{7}{|c|}{ Stations of water samples (hpf / 200mls). } & \multirow{2}{*}{ Total $($ Mean \pm SD). } \\
\hline & A. & B. & C. & D. & E. & F. & G. & \\
\hline Protozoan cysts. & 0 & 0 & 0 & 0 & 0 & 0 & 0 & 0 \\
\hline Protozoan trophozoites. & 0 & 0 & 0 & 0 & 0 & 0 & 0 & 0 \\
\hline Helminths ovae. & 0 & 0 & 0 & 0 & 0 & 0 & 0 & 0 \\
\hline Helminths larvae. & 0 & 0 & 0 & 0 & 0 & 0 & 0 & 0 \\
\hline Helminths adult parasite. & 0 & 0 & 0 & 0 & 0 & 0 & 0 & 0 \\
\hline
\end{tabular}

Table 4. Showed Concentration Levels of Elements in Water Sampled Analysed.

\begin{tabular}{|c|c|c|c|c|c|c|c|c|}
\hline \multirow{2}{*}{$\begin{array}{l}\text { Types of Heavy Metals } \\
\text { Evaluated (mg / l). }\end{array}$} & \multicolumn{7}{|c|}{ Concentration of elements in Stations Sampled $(\mathrm{mg} / 100 \mathrm{mls})$. } & \multirow{2}{*}{ Total $($ Mean \pm SD). } \\
\hline & A. & B. & C. & D. & E. & F. & G. & \\
\hline Cadmium & 0.18 & 0.04 & 0.08 & 0.04 & 0.12 & 0.05 & 0.03 & $0.54(0.08 \pm 0.05)$ \\
\hline Chromium. & 0.02 & 0 & 0.04 & 0.03 & 0.06 & 0.01 & 0.05 & $0.21(0.03 \pm 0.02)$ \\
\hline Copper. & 0.32 & 0 & 0.01 & 0.41 & 0.07 & 0 & 0 & $0.81(0.12 \pm 0.17)$ \\
\hline Fluoride. & 0.08 & 0.11 & 0.05 & 0 & 0 & 0.03 & 0.01 & $0.28(0.04 \pm 0.04)$ \\
\hline Lead. & 0 & 0 & 0.01 & 0 & 0.02 & 0.01 & 0.06 & $0.1(0.01 \pm 0.02)$ \\
\hline Manganese. & 0.25 & 0.17 & 0.02 & 0 & 0.03 & 0.02 & 0.13 & $0.62(0.1 \pm 0.1)$ \\
\hline Nitrite ion. & 0.91 & 0.09 & 0.17 & 0.85 & 0.57 & 0.29 & 1.02 & $3.9(0.6 \pm 0.4)$ \\
\hline
\end{tabular}




\section{Discussion}

The results obtained from this study reveals the physical parametric values ( $\mathrm{pH}$, Temperature and Turbidity), microbiological, and that of the chemical examinations of the water sampled, each from the seven stations collected within the College of Agriculture Community, and the results support the works most authors, especially the World Health Organization where it state that, "many water sources in developing Countries are unhealthy, this is because, they contained harmful physical, chemical and biological agents."

The $\mathrm{pH}$ measured values obtained falls within the W.H.O recommended Standard values ( $\mathrm{pH} 6.5$ to 8.5 ). The highest value recorded out of the seven stations was found to be in station $\mathrm{G}(\mathrm{pH} \mathrm{8.5)}$, and the least was found in station $\mathrm{A}(\mathrm{pH}$ $6.8)$. With regard to the temperature measurement of the water sampled, the parametric value was found to fall within the normal range or room temperature within the tropics. The highest recorded value was found in station $\mathrm{E}$ $\left(32^{\mathrm{O}} \mathrm{C}\right)$, and the least value was found in station $\mathrm{G}$ with a temperature of $22{ }^{\circ} \mathrm{C}$. Among other Physical parametric values of the water sampled measured, Turbidity (TU) was included and results obtained revealed that, only station $G$ has the highest Turbidity Units value with haven $5 \mathrm{TU}$, and the least value was found in station D with 1 TU. Among all the water sampled from the seven stations, only station $\mathrm{G}$ (5 TU) is not fit for consumption and does not met with the W.H.O Recommended Standard Parametric values for table water.

In another finding, the results of the bacteriological examination of the water sampled from the seven stations revealed that, Coliform count exceeded the W.H.O Recommended Standard values for drinking water. The highest in Coli Form Unit per millilitre (CFU / Mls) count was observed in station D (95 CFU / mls), while the least in Coliform count was observed in stations $\mathrm{C}$ and $\mathrm{G}$ (5 CFU / $\mathrm{mls}$ ), each respectively. This indicated that, there were faecal contaminations in all of the water stations examined within the community which rendered the water unhealthy for consumption. The research study on the water sampled, also were subjected to bacteriological examination technique of isolation of Escherichia coli (E. coli), of which only one station was found fit for consumption, and this is station $\mathrm{G}$, which haven $1 \mathrm{CFU} / \mathrm{mls}$. All the rest exceeded the W.H.O Recommended Standard parametric values count. The highest in terms of contamination was found in station A (71 CFU / mls), respectively. In another observation made from the study, Aerobicmesophilic Bacterial count was conducted on the water sampled collected from the seven stations within the said community. The results obtained revealed that, all the water sampled and examined was found to be fit for consumption. This is because; the CFU / mls count does not exceed the W.H.O Recommended Standard parametric value of $300 \mathrm{CFU} / \mathrm{mls}$ count. The highest count was found in station D (260 CFU / $\mathrm{mls}$ ), while the least count was found in station C (0 CFU / $\mathrm{mls}$ ), with no any isolate of Aerobicmesophilic Bacteria.

The water analysis was also subjected to parasitological technique of microscopic analysis for the presence of parasites such as protozoan cysts and their vegetative form (Trophozoites), and the helminths ova, larvae and adult parasites. The results obtained revealed that, there are no any Parasites in any form seen. Hence made the water samples fit for consumption in terms of parasite free.

The determination of the chemical analysis (elements and W.H.O standard value; cadmium $(0.33 \mathrm{mg} / \mathrm{l})$, chromium $(0.05 \mathrm{mg} / \mathrm{l})$, copper $(2.0 \mathrm{mg} / \mathrm{l})$, fluoride $(1.50 \mathrm{mg} / \mathrm{l})$, lead $(0.01 \mathrm{mg} / \mathrm{l})$, manganese $(0.05 \mathrm{mg} / \mathrm{l})$ and nitrite ion $(4.6 \mathrm{mg} / \mathrm{l}))$ on the water sampled from the seven stations, it revealed that cadmium, copper, fluoride and nitrite ion in all of the water sampled from the seven stations, the values falls within the range of the W.H.O recommended standard values. Also, same with chromium, except that in station $\mathrm{E}$ $(0.06 \mathrm{mg} / \mathrm{l})$, where the value exceeded that of W.H.O standard, lead value exceeded in stations E $(0.02 \mathrm{mg} / \mathrm{l})$ and $\mathrm{G}(0.06 \mathrm{mg} / \mathrm{l})$ and manganese value exceeded in stations $\mathrm{A}$ $(0.25 \mathrm{mg} / \mathrm{l}), \mathrm{B}(0.17 \mathrm{mg} / \mathrm{l})$ and $\mathrm{G}(0.13 \mathrm{mg} / \mathrm{l})$. Among the all of the heavy metals determined and evaluated on the water sampled from the seven stations within the said community and found to exceeded the W.H.O recommended standard values are chromium in station $\mathrm{E}$, lead in stations $\mathrm{E}$ and $\mathrm{G}$, and manganese in stations A, B and G only which make the water unfit able and unsafe for consumption in terms of the chemical determined. But all of the rest of the water the stations are fit and safe for consumption and domestic activities in terms of the chemical evaluated in the samples. The data obtained were subjected to statistical tool of analysis by using total, mean and standard deviation, ascertained the significance, and verified the dispersions and the central tendency of the variables as described by Stroud \& Booth, (2001).

\section{Conclusion}

The results obtained from this study revealed that the physical parametric values ( $\mathrm{pH}$, temperature and turbidity), microbiological and that of the chemical examinations of the water sampled from stations each, collected within the College of Agriculture Community, were observed and recorded. Values obtained from the measurement of the water sampled met the W.H.O recommended standard parametric values for table water in terms of $\mathrm{pH}$ and temperature. Among all the water sampled only one station is not fit for consumption and does not met with the W.H.O recommended standard parametric values for table water. Bacteriological examination of the water sampled, revealed that, Coliform count exceeded that of the W.H.O recommended standard values for drinking water. Bacteriological examination technique of isolation of Escherichia coli (E. coli), only one station was found fit for consumption. Aerobicmesophilic Bacterial count was 
conducted revealed that, all the water samples examined were found fit for consumption. This is because; the CFU / mls count does not exceed the W.H.O recommended standard parametric value of $300 \mathrm{CFU} / \mathrm{mls}$ count. The parasitological technique of microscopic analysis of the water sampled for the presence of water borne parasites revealed that, there are no any parasites in any form seen. Hence made the water samples fit for consumption in terms of parasite free. The water sampled from the seven stations within the said community and found to exceeded the W.H.O recommended standard values are chromium in station $\mathrm{E}$, lead in stations $\mathrm{E}$ and $\mathrm{G}$, and manganese in stations A, B and $G$ only which make the water unwholesome for consumption in terms of the chemical being determined. But all of the rest of the water sampled from these stations are fit and safe for consumption and domestic activities in terms of the chemical evaluated in some samples. The variables obtained are analysed, results found are significant and accepted.

\section{Recommendations}

Based on the finding of this research study, we recommended that; the community of the studied area should be enlightening on the World Health Organizations Recommended Standard Parametric values for safe drinking water and it purification. The Government, Non Governmental Organizations or any authority concerned should assists and build more Bore Holes with polythene pipes for safe water distributions for the community studied. Further intensive research studies in the studied area and its environs are highly recommended.

\section{Acknowledgment}

It is a great pleasure to acknowledge the great roles played by the Mohamet Lawan College of Agriculture, Maiduguri, North - Eastern Nigeria, for allowing us run to this research in the Institute, and great appreciation goes to the entire staff of the Vet. Research Lab., Department of Veterinary Microbiology and Parasitology, University of Maiduguri, Nigeria.

\section{References}

[1] Abdullahi, Hala, "Importance and existence of water; In: Effect of Domestic Liquid Waste on Ground Water Quality of Shallow Well: A Case Study of Moduganari, Maisandari Ward, Maiduguri” A Final Year Project (Unpublished), Department of Agriculture and Bio-Environmental Engineering, Ramat Polytechnic, Maiduguri; Pp 4 - 8, 2013.

[2] AOAC, "Official Methods of Analysis, In: Association of Official Analytical Chemists, AOAC Press; Gaithersburg, Washington D.C, USA, $15^{\text {th }}$ Edition; Pp. 71 - 92, 1990.

[3] Bonnie, Worthington-Roberts, "Microsoft ${ }^{\circledR}$ Encarta ${ }^{\circledR} 2008$ " [DVD]. Remond, WA: Microsoft Corporation, (C) 19972007, 2008.

[4] Cainncross, G and Feachen, R.G., "Environmental Health Engineering in the Tropic", In: Wiley, an Introductory Text Book, $4^{\text {th }}$ Edition; Pp. $144-149,1983$.

[5] Frazier, W.C. and Westhoff, D.C., "Food Microbiology", McGraw Hill Books Co, $4^{\text {th }}$ Edition; Pp. 63 - 487, 1988.

[6] Gardon, M. Fair., "SilversionWater \& West Water Technology", (Silversion), Ohn - Wiley \& Sons Ltd, $1^{\text {st }}$ Edition; Pp. 1 - 68, 1978.

[7] Gwana, A.M; Auwal, M.S; Bagudu, B.Y. \& Gazali, Y.A., "Study Area and Location, In: Comparative of Parasitological Diagnostic Techniques in the Survey of Haemoparasites of Camel Slaughtered in Maiduguri Central Abattoir, North - eastern Nigeria", Journal of Laboratory Science, Volume 1, number 2; Pp. 57 - 65.

[8] John, Hart, "Microsoft ${ }^{\circledR}$ Encarta ${ }^{\circledR} 2008$ ", [DVD]. Remond, WA: Microsoft Corporation, (c) 1997-2007, 2008.

[9] Cheesbrough, M., "Water Related Disease and Testing of Water Supply, In: District Laboratory Practice in Tropical Countries", Part Two, $2^{\text {nd }}$ Edition, Cambridge University Press; Pp. 143 - 157, 2010.

[10] Philip, Mathews, "Water is Special about Water, In: Advance Chemistry", Cambridge University Press, U.K, Low Price Edition; Pp. 558 - 568, 2004.

[11] Shmueli, Deborah F., "Water Quality in International River Basin, Political Geography” 18: Pp 437 - 476, 1999.

[12] Stroud, K.A and Booth, D.J., "Statistical Package, Engineering Mathematics", WWW. Palgrave.Com / Stroud Palgrave, GB, London, $5^{\text {th }}$ Edition; 1130 - 1139, 2001.

[13] Wikipedia, "Drinking Water Quality Standard, Wikipedia Encyclopaedia", Pp 1 - 4, 2013.

[14] World Health Organisation, "Guidelines for Drinking Water Quality”, $3^{\text {rd }}$ Edition, Volume 1; Pp. 34 - 78, 2004.

[15] World Health Organisation, "Guidelines for Drinking Water Quality”, 4 ${ }^{\text {rd }}$ Edition, Volume 1; Pp. 23 - 30, 2011. 